\title{
Bond reactivity indices approach analysis of the [2+2] cycloaddition of jatrophane skeleton diterpenoids from Euphorbia gaditana Coss to tetracyclic gaditanone
}

\author{
M. Eugenia Flores-Giubi a,b , Jose Manuel Botubol-Ares ${ }^{a}$, María J. Durán-Peña a, \\ Felipe Escobar-Montaño ${ }^{a}$, David Zorrilla ${ }^{\mathrm{c}}$, Jesús Sánchez-Márquez ${ }^{\mathrm{c}}$, Eduardo Muñoz ${ }^{\mathrm{d}}$, \\ Antonio J. Macías-Sánchez ${ }^{\text {a }}$, Rosario Hernández-Galán ${ }^{\text {a, * }}$ \\ ${ }^{a}$ Departamento de Química Orgánica, Facultad de Ciencias, Campus Universitario Río San Pedro s/n, Universidad de Cádiz, 11510, Puerto Real, Cádiz, Spain \\ ${ }^{\mathrm{b}}$ Departamento de Química Biológica, Facultad de Ciencias Químicas, Universidad Nacional de Asunción, San Lorenzo, Departamento Central, Paraguay \\ ${ }^{\mathrm{c}}$ Departamento de Química Física, Facultad de Ciencias, Universidad de Cádiz, Campus Universitario Puerto Real s/n, 11510, Puerto Real, Cádiz, Spain \\ d Department of Cell Biology, Physiology and Immunology, Instituto Maimónides de Investigación Biomédicas de Córdoba (IMIBIC), Reina Sofía University Hospital, \\ University of Córdoba, C/ Maria Virgen y Madre s/n, 14004, Córdoba, Spain
}

\section{A R T I C L E I N F O}

\section{Keywords:}

Euphorbia gaditana Coss

Euphorbiaceae

Biosynthesis

Diterpene

Jatrophane

Gaditanane

$[2+2]$ cycloaddition

\begin{abstract}
A B S T R A C T
The reaction mechanism of the intramolecular $[2+2]$ cycloaddition from a jatrophane precursor to the gaditanane skeleton, an unprecedented 5/6/4/6-fused tetracyclic ring framework recently isolated from Euphorbia spp., was studied using the bond reactivity indices approach. Furthermore, six diterpenoids, including three undescribed jatrophanes isolated from $E$. gaditana Coss, were described. The structures of these compounds were deduced by a combination of 2D NMR spectroscopy and ECD data analysis.
\end{abstract}

\section{Introduction}

The genus Euphorbia has attracted a great attention in the search for natural-product-based drugs as an abundant source of bioactive terpenoids (Brooks et al., 1987; Stockwell, 2004; Shi et al., 2008; Mai et al., 2018a; Wan et al., 2018; Zhao et al., 2018). With over 2000 known species is the largest genus in the plant family Euphorbiaceae (Jassbi, 2006), and no less than 400 diterpenoids isolated from plants of that genus exhibit relevant biological activities (Shi et al., 2008; Vasas et al., 2012; Vasas and Hohmann, 2014; Wang et al., 2015). Many plants species of the Euphorbiaceae family produce diterpenoids with jatrophane, lathyrane, tigliane, daphnane, ingenane, or myrsinane skeleta which show a broad range of interesting pharmacological properties such as antitumor and multidrug resistance reversing activities (Tian et al., 2013, 2014; Vasas and Hohmann, 2014; Fei et al., 2016; Wan et al., 2016; Wang et al., 2015; Zhang et al., 2019). The ability of members of these classes of compounds to modulate protein kinase $\mathrm{C}$ (PKCs) (Durán-Peña et al., 2014) is associated with a wide variety of biological activities such as cell differentiation (Weinstein et al., 1979; Kinzel et al., 1984), skin inflammation (Kinghorn, 1979), tumor promotion (Olivier et al., 1992; Roux et al., 2004), cytotoxicity (Blumberg and Szallasi, 1994), latent HIV-1 reactivation (Kulkosky et al., 2001; Bocklandt et al., 2003; Daoubi et al., 2007; Márquez et al., 2008; Andersen et al., 2018), and recently in neural precursor proliferation (Castro-González et al., 2013, 2015; Geribaldi-Doldan et al., 2016; Flores-Giubi et al., 2019).

Among Euphorbiaceae family diterpenes, jatrophane diterpenoids are ubiquitous metabolites of genera Euphorbia and Jatropha (Sabandar et al., 2013). The general structure of the jatrophane skeleton is characterized by a $5 / 12$ fused-ring system and they are usually substituted by a variety of acyl groups to form polyesters (Fattahian et al., 2020). Interestingly, it has been described that some jatrophane diterpenoids have anti-cancer activity (Ling et al., 2019; Meng et al., 2020), as well as microtubule interacting activity (Miglietta et al., 2003) and act in vitro against HIV-1 (Bedoya et al., 2009) and CHIKV viruses (Esposito et al., 2016; Remy and Litaudon, 2019); furthermore, they are considered

\footnotetext{
* Corresponding author.

E-mail address: rosario.hernandez@uca.es (R. Hernández-Galán).
} 
among the most potent modulators of P-glycoproteins that reverse multidrug resistance (Hohmann et al., 2002; Corea et al., 2003; Esposito et al., 2017; Hu et al., 2018; Krstic et al., 2018).

Euphorbia gaditana Coss., belonging to the genus Euphorbia, is an endangered species from Southern Spain (western Andalusia) and Northern Africa (Algeria and Tunisia). In a previous chemical investigation of E. gaditana Coss, a previously undescribed jatrophane (1) together with an undescribed diterpenoid (2) with an unprecedented 5/ 6/4/6-fused tetracyclic ring skeleton, were isolated from the aerial parts of this plant. The name gaditanane was proposed for that carbon skeleton. A suggested biosynthetic relationship between both compounds was also established by chemical correlation (Flores-Giubi et al., 2017). Simultaneously, in a report from Mai et al. (2017), two other undescribed jatrophane-derived diterpenoid esters with a 5/6/4/6-fused tetracyclic ring skeleton, heliosterpenoids $\mathrm{A}$ and $\mathrm{B}$, were isolated from E. helioscopia and were found to be potent inhibitors of $\beta$-glycoproteins and exhibited cytotoxic activity.

Therefore, as a part of our ongoing research on the identification and study of the reactivity of undescribed bioactive compounds potentially capable of modulating PKC isoforms (Daoubi et al., 2007; Flores-Giubi et al., 2019), a detailed study of the specialised metabolites in the roots and aerial parts of E. gaditana Coss has been conducted. A study of the cyclization to gaditanone from jathrophane metabolites isolated from E. gaditana Coss, has been modeled using bond reactivity indices approach.

\section{Results and discussion}

\subsection{Isolation and chemical characterization}

The petroleum ether and dichloromethane extracts from the aerial parts and roots of E. gaditana Coss were further purified leading to the isolation and structural elucidation of three undescribed jatrophanes (3-5), along with the three previously known compounds (1, 2 and 6) (Fig. 1). The structures of compounds 3-5 were established based on spectroscopy analysis including $1 \mathrm{D}$ and 2D NMR and HRESIMS experiments. Absolute configuration for compound $\mathbf{3}$ was established by comparison among its experimental and calculated ECD, where the starting point conformation used for computational calculations was deduced from NOESY data. This, in turn, supported the proposed absolute configurations given for compounds 4-5.

Analysis of the NMR data showed that $\mathbf{3 - 5}$ are closely related structurally to other jatrophane-skeleton diterpenoids with acyloxy groups previously described in the literature from E. serrulata (Hohmann et al., 2002), E. platyphyllos (Hohmann et al., 2003), E. pubescens (Valente et al., 2004) and with jatrophane 1 from E. gaditana Coss (Flores-Giubi et al., 2017).
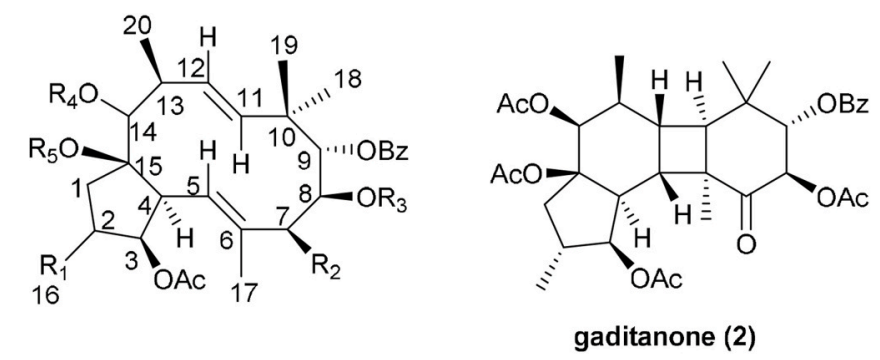

1: $\mathrm{R}_{1}=\alpha-\mathrm{CH}_{3}, \mathrm{R}_{2}=\mathrm{OH}, \mathrm{R}_{3}=\mathrm{Ac}, \mathrm{R}_{4}=\beta-\mathrm{Ac}, \mathrm{R}_{5}=\mathrm{Ac}$
3: $\mathrm{R}_{1}=\alpha-\mathrm{CH}_{3}, \mathrm{R}_{2}=\mathrm{OH}, \mathrm{R}_{3}=\mathrm{Ac}, \mathrm{R}_{4}=\alpha-\mathrm{Ac}, \mathrm{R}_{5}=\mathrm{H}$
4: $\mathrm{R}_{1}=\alpha-\mathrm{CH}_{3}, \mathrm{R}_{2}=\mathrm{OAc}, \mathrm{R}_{3}=\mathrm{H}, \mathrm{R}_{4}=\beta-A c, \mathrm{R}_{5}=\mathrm{Ac}$
5: $\mathrm{R}_{1}=\beta-\mathrm{CH}_{3}, \mathrm{R}_{2}=\mathrm{OH}, \mathrm{R}_{3}=\mathrm{Ac}, \mathrm{R}_{4}=\beta-A c, \mathrm{R}_{5}=\mathrm{Ac}$
6: $\mathrm{R}_{1}=\alpha-\mathrm{CH}_{3}, \mathrm{R}_{2}==\mathrm{O}, \mathrm{R}_{3}=\mathrm{Ac}, \mathrm{R}_{4}=\beta-\mathrm{Ac}, \mathrm{R}_{5}=\mathrm{Ac}$

Fig. 1. Structures of compounds 1-6.
Compound 3 was isolated as an amorphous solid, and its molecular formula $\mathrm{C}_{33} \mathrm{H}_{44} \mathrm{O}_{10}$ (12 unsaturations) was deduced on the basis of the observed sodium adduct ion in its HRESIMS $\left(m / z 623.2834[\mathrm{M}+\mathrm{Na}]^{+}\right)$. Both ${ }^{1} \mathrm{H}$ and ${ }^{13} \mathrm{C}$ NMR data analysis (Table 1 ) revealed four ester residues attributable to the presence of three acetoxy groups and one benzoyloxy group. In addition of these signals, ${ }^{13} \mathrm{C}$ NMR and DEPT spectra displayed signals for the remaining 20 skeletal carbons, encompassing five methyl groups, one methylene group, 11 methine groups (including five oxygenated $\mathrm{sp}^{3}$ carbons and three olefinic carbons), and three nonprotonated carbons (including one oxygenated $\mathrm{sp}^{3}$ carbon and one olefinic carbon).

The HMBC cross-peaks from H-8 $\left(\delta_{\mathrm{H}} 5.34 \mathrm{ppm}\right)$ and $\mathrm{H}-14\left(\delta_{\mathrm{H}} 4.79\right.$ $\mathrm{ppm})$ to $\delta_{\mathrm{C}} 169.2$ and $170.4 \mathrm{ppm}$, respectively, indicated two acetoxy groups attached to C-8 and C-14 whereas the benzoate chain was located at C-9 due to HMBC cross-peaks from $\mathrm{H}-9\left(\delta_{\mathrm{H}} 4.60 \mathrm{ppm}\right)$ to carbonyl carbon of the benzoyl group at $\delta_{\mathrm{C}} 167.4 \mathrm{ppm}$. The remaining acetoxy group could not be directly attached by HMBC experiments due to the lack of direct correlations. The comparison of the chemical shifts and coupling constants of $\mathrm{H}-3$ and $\mathrm{H}-2$ with those observed in the literature for other related jatrophanes pointed out that it must be located at C-3 (Hohmann et al., 2002, 2003; Valente et al., 2004; Flores-Giubi et al., 2017; Mai et al., 2017). Finally, the free hydroxyl groups were deduced to be attached to C-7 and C-15. The gCOSY correlations observed for protons $\mathrm{H}-7\left(\delta_{\mathrm{H}} 4.16 \mathrm{ppm}\right)$ and $\mathrm{OH}-7\left(\delta_{\mathrm{H}} 4.85 \mathrm{ppm}\right)$ indicated the presence of a hydroxyl group at C-7. The remaining one hydroxyl group must be located at $\mathrm{C}-15$ due to the shielding of that nucleus in the ${ }^{13} \mathrm{C}$ NMR spectrum in comparison to other related-jatrophanes (Table S9) (Fig. 2) (Hohmann et al., 2002, 2003; Valente et al., 2004; Flores-Giubi et al., 2017; Mai et al., 2017). A new signal at $\delta_{\mathrm{H}} 7.27 \mathrm{ppm}$ in the ${ }^{1} \mathrm{H}$ NMR spectrum in $\mathrm{C}_{6} \mathrm{D}_{6}$, which partially exchanged with $\mathrm{D}_{2} \mathrm{O}$, confirmed the hydroxyl group at C-15 (Table S8 and Fig. S14).

The relative configuration of $\mathbf{3}$ was deduced by the interpretation of the NOESY spectrum. The correlations of $\mathrm{H}-4 / \mathrm{H}_{3}-17 / \mathrm{H}-7 / \mathrm{H}-8$ and $\mathrm{H}-4 /$ $\mathrm{H}-13 / \mathrm{H}-11$ indicated $\alpha$-orientations for those protons, whereas the correlations of $\mathrm{H}-5 / \mathrm{H}-9$ were used to place these protons on the opposite face of the macrocycle. The NOESY correlations of $\mathrm{H}-11 / \mathrm{H}_{3}-17 / \mathrm{H}-13$ and the coupling constant of $J_{11,12}=15.5 \mathrm{~Hz}$ revealed the $E$-geometry of the C-11/C-12 double bond, while the $E$ stereochemistry of the C-5/C- 6 olefin linkage was deduced from NOESY correlations between $\mathrm{H}-4 / \mathrm{H}_{3}-$ 17 and $\mathrm{H}-5 / \mathrm{H}-9$. Further NOESY correlations of $\mathrm{H}_{3}-16 / \mathrm{H}-3 / \mathrm{H}-4$ and $\mathrm{H}-$ $12 / \mathrm{H}_{3}-20 / \mathrm{H}-14$ revealed their proximity in space (Fig. 3 ). Moreover, the coupling constant $J_{14,13}=10.3 \mathrm{~Hz}$ (Table 1) was compatible with an anti-disposition of $\mathrm{H}-13$ and $\mathrm{H}-14$ and it was in agreement with the values described in literature for other related-jatrophanes (Valente et al., 2004; Mai et al., 2018b).

On the basis of the $\alpha$-assumed configuration of $\mathrm{H}-4$ and $\beta$-orientation of 15-OH, characteristic of all jatrophane-type diterpene derivatives isolated to date (Fakunle et al., 1989; Tian et al., 2014), and NOESY correlations the absolute configuration for $\mathbf{3}$ was suggested to be assigned as $2 R, 3 S, 4 S, 7 S, 8 S, 9 S, 13 S, 14 R, 15 R$. This absolute configuration of 3 was supported by comparison of the experimental ECD spectrum with the computed ECD spectrum calculated from quantum mechanical time-dependent density functional theory (TDDFT) calculations with B3LYP/6-31G++ (d,p) level of theory, using the Gaussian 16 program (Li et al., 2010). The theoretically calculated ECD spectrum of $\mathbf{3}$ was in good agreement with the experimental ECD spectrum (Fig. 4).

Compounds 4 and 5 showed the same molecular formula of $\mathrm{C}_{35} \mathrm{H}_{46} \mathrm{O}_{11}$ based on a sodium adduct ion at $m / z=665.2946[\mathrm{M}+\mathrm{Na}]^{+}$ and $m / z=665.2944[\mathrm{M}+\mathrm{Na}]^{+}$, respectively in their HRESIMS spectra. Both the ${ }^{1} \mathrm{H}$ and ${ }^{13} \mathrm{C}$ NMR data (Table 1 ) indicated that the structure of compounds 4 and 5 closely resembled jatrophane 3 , the difference being the presence and position of an additional acetoxy group.

In contrast to $\mathbf{3}$, an acetyl group in compound $\mathbf{4}$ is located at C-7, which was confirmed by the HMBC cross-peak between H-7 $\left(\delta_{\mathrm{H}} 5.09\right.$ $\mathrm{ppm})$ and $\delta_{\mathrm{C}} 170.0 \mathrm{ppm}$. The gCOSY spectrum enabled assignment of the 
Table 1

${ }^{1} \mathrm{H}(500 \mathrm{MHz})$ and ${ }^{13} \mathrm{C}(125 \mathrm{MHz}) \mathrm{NMR}$ data for $\mathbf{3}-\mathbf{5}$ (in $\mathrm{CDCl}_{3}, \delta$ in ppm).

\begin{tabular}{|c|c|c|c|c|c|c|}
\hline \multirow[b]{2}{*}{ No. } & \multicolumn{2}{|l|}{3} & \multicolumn{2}{|l|}{4} & \multicolumn{2}{|l|}{5} \\
\hline & $\begin{array}{l}\delta_{\mathrm{H}}(J \text { in } \\
\mathrm{Hz})\end{array}$ & $\begin{array}{l}\delta_{\mathrm{C}} \\
\text { mult }\end{array}$ & $\begin{array}{l}\delta_{\mathrm{H}}(J \text { in } \\
\mathrm{Hz})\end{array}$ & $\delta_{\mathrm{C}}$, mult & $\begin{array}{l}\delta_{\mathrm{H}}(J \text { in } \\
\mathrm{Hz})\end{array}$ & $\delta_{\mathrm{C}}$, mult \\
\hline $1 \alpha$ & $1.21, \mathrm{~m}$ & $\begin{array}{l}41.9, \\
\mathrm{CH}_{2}\end{array}$ & $\begin{array}{l}1.34, \text { dd } \\
(14.4, \\
12.5)\end{array}$ & $\begin{array}{l}41.1, \\
\mathrm{CH}_{2}\end{array}$ & $\begin{array}{l}2.46, \text { dd } \\
(14.1, \\
6.2)\end{array}$ & $43.2, \mathrm{CH}_{2}$ \\
\hline $1 \beta$ & $\begin{array}{l}1.67, \text { dd } \\
(13.0, \\
5.8)\end{array}$ & & $\begin{array}{l}3.54, \text { dd } \\
(14.4, \\
5.7)\end{array}$ & & $\begin{array}{l}2.31, \mathrm{t} \\
(14.1)\end{array}$ & \\
\hline 2 & $2.46, \mathrm{~m}$ & $\begin{array}{l}35.0 \\
\mathrm{CH}\end{array}$ & $2.17, \mathrm{~m}$ & $\begin{array}{l}36.5, \\
\mathrm{CH}\end{array}$ & $1.99, \mathrm{~m}$ & $36.9, \mathrm{CH}$ \\
\hline 3 & $\begin{array}{l}4.38, \text { dd } \\
(10.5, \\
9.2)\end{array}$ & $\begin{array}{l}82.5, \\
\mathrm{CH}\end{array}$ & $\begin{array}{l}4.62, \mathrm{t} \\
(9.2)\end{array}$ & $\begin{array}{l}80.7, \\
\mathrm{CH}\end{array}$ & $\begin{array}{l}5.18, \mathrm{t} \\
(4.6)\end{array}$ & 78.6, CH \\
\hline 4 & $\begin{array}{l}3.53, \text { dd } \\
(11.7, \\
9.2)\end{array}$ & $\begin{array}{l}43.0, \\
\mathrm{CH}\end{array}$ & $\begin{array}{l}3.24 \text {, dd } \\
(10.8, \\
9.2)\end{array}$ & $\begin{array}{l}46.3, \\
\mathrm{CH}\end{array}$ & $\begin{array}{l}2.99, \text { dd } \\
(10.0 \text {, } \\
4.6)\end{array}$ & $48.5, \mathrm{CH}$ \\
\hline 5 & $\begin{array}{l}5.74, \\
d(11.7)\end{array}$ & $\begin{array}{l}122.6 \text {, } \\
\mathrm{CH}\end{array}$ & $\begin{array}{l}5.53, \\
d(10.8)\end{array}$ & $\begin{array}{l}120.8, \\
\mathrm{CH}\end{array}$ & $\begin{array}{l}5.88, \\
d(10.0)\end{array}$ & 121.4, CH \\
\hline 6 & & $\begin{array}{l}136.2, \\
\mathrm{C}\end{array}$ & & $\begin{array}{l}131.7, \\
\text { C }\end{array}$ & & 133.4, C \\
\hline 7 & 4.16 , brs & $\begin{array}{l}77.5 \text {, } \\
\mathrm{CH}\end{array}$ & 5.09, brs & $\begin{array}{l}81.6, \\
\mathrm{CH}\end{array}$ & 4.10 , brs & $77.2, \mathrm{CH}$ \\
\hline 8 & 5.34, brd & $\begin{array}{l}69.3, \\
\mathrm{CH}\end{array}$ & $\begin{array}{l}3.91 \\
\text { d }(9.2)\end{array}$ & $\begin{array}{l}68.2, \\
\mathrm{CH}\end{array}$ & $\begin{array}{l}5.24, \\
d(4.0)\end{array}$ & $69.9, \mathrm{CH}$ \\
\hline 9 & $\begin{array}{l}4.60 \\
d(5.2)\end{array}$ & $\begin{array}{l}74.2, \\
\mathrm{CH}\end{array}$ & $\begin{array}{l}5.24, \\
\text { d (1.7) }\end{array}$ & $\begin{array}{l}74.2 \text {, } \\
\mathrm{CH}\end{array}$ & $\begin{array}{l}4.87 \\
d(4.0)\end{array}$ & 73.9, CH \\
\hline 10 & & 39.7, C & & $39.5, \mathrm{C}$ & & $39.3, \mathrm{C}$ \\
\hline 11 & $\begin{array}{l}5.17 \\
\text { d (15.5) }\end{array}$ & $\begin{array}{l}136.3, \\
\mathrm{CH}\end{array}$ & $\begin{array}{l}5.14, \\
\text { d (16.0) }\end{array}$ & $\begin{array}{l}\text { 135.7, } \\
\mathrm{CH}\end{array}$ & $\begin{array}{l}5.10, \\
d(15.6)\end{array}$ & 134.5, CH \\
\hline 12 & $\begin{array}{l}5.51, \text { dd } \\
(15.5, \\
10.0)\end{array}$ & $\begin{array}{l}129.6 \text {, } \\
\mathrm{CH}\end{array}$ & $\begin{array}{l}5.80, \text { dd } \\
(16.0, \\
7.6)\end{array}$ & $\begin{array}{l}131.8, \\
\mathrm{CH}\end{array}$ & $\begin{array}{l}5.54, \text { dd } \\
(15.6, \\
9.4)\end{array}$ & 130.6, CH \\
\hline 13 & $2.34, \mathrm{~m}$ & $\begin{array}{l}42.0 \text {, } \\
\mathrm{CH}\end{array}$ & $2.53, \mathrm{~m}$ & $\begin{array}{l}38.4, \\
\mathrm{CH}\end{array}$ & $2.65, \mathrm{~m}$ & $38.6, \mathrm{CH}$ \\
\hline 14 & $\begin{array}{l}4.79 \\
\text { d (10.3) }\end{array}$ & $\begin{array}{l}79.2, \\
\mathrm{CH}\end{array}$ & $\begin{array}{l}4.94 \\
\text { d (2.8) }\end{array}$ & $\begin{array}{l}80.5, \\
\mathrm{CH}\end{array}$ & $\begin{array}{l}4.94 \\
d(2.4)\end{array}$ & 79.4, CH \\
\hline 15 & & $83.6, \mathrm{C}$ & & 93.4, C & & $91.1, \mathrm{C}$ \\
\hline 16 & $\begin{array}{l}0.98 \\
\text { d (6.4) }\end{array}$ & $\begin{array}{l}16.4, \\
\mathrm{CH}_{3}\end{array}$ & $\begin{array}{l}0.99 \\
d(6.6)\end{array}$ & $\begin{array}{l}16.7 \\
\mathrm{CH}_{3}\end{array}$ & $\begin{array}{l}0.92,{ }^{f} \\
d(6.8)\end{array}$ & $\begin{array}{l}13.2,{ }^{\mathrm{h}} \\
\mathrm{CH}_{3}\end{array}$ \\
\hline 17 & $1.78, \mathrm{~s}$ & $\begin{array}{l}16.0 \\
\mathrm{CH}_{3}\end{array}$ & $\begin{array}{l}1.73 \\
\text { d }(1.2)\end{array}$ & $\begin{array}{l}15.9, \\
\mathrm{CH}_{3}\end{array}$ & $1.78, \mathrm{~s}$ & $16.1, \mathrm{CH}_{3}$ \\
\hline 18 & $1.12,{ }^{\mathrm{a}} \mathrm{s}$ & $\begin{array}{l}21.1,{ }^{b} \\
\mathrm{CH}_{3}\end{array}$ & $1.14, \mathrm{~s}$ & $\begin{array}{l}21.0 \\
\mathrm{CH}_{3}\end{array}$ & $1.09, \mathrm{~s}$ & 21.1, $\mathrm{CH}_{3}$ \\
\hline 19 & $1.12,{ }^{\mathrm{a}} \mathrm{s}$ & $\begin{array}{l}23.4,{ }^{b} \\
\mathrm{CH}_{3}\end{array}$ & $1.05, \mathrm{~s}$ & $\begin{array}{l}22.9 \\
\mathrm{CH}_{3}\end{array}$ & $1.11, \mathrm{~s}$ & $23.4, \mathrm{CH}_{3}$ \\
\hline 20 & $\begin{array}{l}0.94, \\
d(6.6)\end{array}$ & $\begin{array}{l}20.2, \\
\mathrm{CH}_{3}\end{array}$ & $\begin{array}{l}0.95 \\
d(7.0)\end{array}$ & $\begin{array}{l}20.0 \\
\mathrm{CH}_{3}\end{array}$ & $\begin{array}{l}0.91,{ }^{f} \\
d(6.8)\end{array}$ & $19.9,{ }^{\mathrm{h}} \mathrm{CH}_{3}$ \\
\hline OH-7 & $\begin{array}{l}4.85 \\
\text { d (3.1) }\end{array}$ & & & & 3.97 , brs & \\
\hline $\mathrm{OH}-8$ & & & $\begin{array}{l}3.02, \\
d(9.2)\end{array}$ & & & \\
\hline $\mathrm{CO}-3$ & & $\begin{array}{l}\text { 171.5, } \\
\text { C }\end{array}$ & & $\begin{array}{l}170.8, \\
\text { C }\end{array}$ & & $170.8,{ }^{\mathrm{i}} \mathrm{C}$ \\
\hline $\begin{array}{c}\mathrm{COCH}_{3-} \\
3 \\
\mathrm{CO}-7\end{array}$ & $1.99, \mathrm{~s}$ & $\begin{array}{l}20.9 \\
\mathrm{CH}_{3}\end{array}$ & $1.92, \mathrm{~s}$ & $\begin{array}{l}20.6, \\
\mathrm{CH}_{3} \\
170.0,{ }^{\mathrm{d}} \\
\mathrm{C}\end{array}$ & $2.04,^{g} \mathrm{~s}$ & $21.0,{ }^{\mathrm{j}} \mathrm{CH}_{3}$ \\
\hline $\begin{array}{c}\mathrm{COCH}_{3-} \\
7\end{array}$ & & & $2.35,^{\mathrm{c}} \mathrm{s}$ & $\begin{array}{l}20.8,{ }^{e} \\
\mathrm{CH}_{3}\end{array}$ & & \\
\hline $\mathrm{CO}-8$ & & $\begin{array}{l}169.2, \\
\text { C }\end{array}$ & & & & $169.6,{ }^{\mathrm{i}} \mathrm{C}$ \\
\hline $\begin{array}{l}\mathrm{COCH}_{3-}^{-} \\
8\end{array}$ & $1.78, \mathrm{~s}$ & $\begin{array}{l}20.8, \\
\mathrm{CH}_{3}\end{array}$ & & & $1.91,,^{g} \mathrm{~s}$ & $20.9,{ }^{\mathrm{j}} \mathrm{CH}_{3}$ \\
\hline CO-9 & & $\begin{array}{l}167.4, \\
\text { C }\end{array}$ & & $\begin{array}{l}164.3, \\
C\end{array}$ & & 167.0, C \\
\hline COBz-9 & & & & & & \\
\hline $1^{\prime}$ & & $\begin{array}{l}129.3, \\
\text { C }\end{array}$ & & $\begin{array}{l}130.0, \\
\text { C }\end{array}$ & & 129.6, C \\
\hline $2^{\prime}, 6^{\prime}$ & $\begin{array}{l}8.04 \\
\text { d ( } 8.2)\end{array}$ & $\begin{array}{l}129.7, \\
\mathrm{CH}\end{array}$ & $\begin{array}{l}8.04 \\
\text { d (8.4) }\end{array}$ & $\begin{array}{l}129.4 \text {, } \\
\mathrm{CH}\end{array}$ & $\begin{array}{l}8.07 \\
d(8.2)\end{array}$ & 129.7, CH \\
\hline $3^{\prime}, 5^{\prime}$ & $7.47, \mathrm{~m}$ & $\begin{array}{l}128.7, \\
\mathrm{CH}\end{array}$ & $7.48, \mathrm{~m}$ & $\begin{array}{l}128.8, \\
\mathrm{CH}\end{array}$ & $7.48 \mathrm{~m}$ & 128.6, CH \\
\hline $4^{\prime}$ & $7.61, \mathrm{~m}$ & $\begin{array}{l}133.8, \\
\mathrm{CH}\end{array}$ & $7.60, \mathrm{~m}$ & $\begin{array}{l}\text { 133.4, } \\
\mathrm{CH}\end{array}$ & $7.61, \mathrm{~m}$ & 133.6, CH \\
\hline
\end{tabular}

Table 1 (continued)

\begin{tabular}{|c|c|c|c|c|c|c|}
\hline \multirow[b]{2}{*}{ No. } & \multicolumn{2}{|l|}{3} & \multicolumn{2}{|l|}{4} & \multicolumn{2}{|l|}{5} \\
\hline & $\begin{array}{l}\delta_{\mathrm{H}}(J \text { in } \\
\mathrm{Hz})\end{array}$ & $\begin{array}{l}\delta_{\mathrm{C}}, \\
\text { mult }\end{array}$ & $\begin{array}{l}\delta_{\mathrm{H}}(J \text { in } \\
\mathrm{Hz})\end{array}$ & $\delta_{\mathrm{C}}$, mult & $\begin{array}{l}\delta_{\mathrm{H}}(J \text { in } \\
\mathrm{Hz})\end{array}$ & $\delta_{\mathrm{C}}$, mult \\
\hline $\mathrm{CO}-14$ & & $\begin{array}{l}\text { 170.4, } \\
\text { C }\end{array}$ & & $\begin{array}{l}\text { 171.0, } \\
\text { C }\end{array}$ & & $171.3,{ }^{\mathrm{i}} \mathrm{C}$ \\
\hline $\begin{array}{c}\mathrm{COCH}_{3}- \\
14\end{array}$ & $2.14, \mathrm{~s}$ & $\begin{array}{l}21.2 \\
\mathrm{CH}_{3}\end{array}$ & $2.12, \mathrm{~s}$ & $\begin{array}{l}20.8, \\
\mathrm{CH}_{3}\end{array}$ & $2.13,^{g} \mathrm{~s}$ & $22.9,{ }^{\mathrm{j}} \mathrm{CH}_{3}$ \\
\hline CO-15 & & & & $\begin{array}{l}170.0,{ }^{\mathrm{d}} \\
\mathrm{C}\end{array}$ & & $169.1,{ }^{\mathrm{i}} \mathrm{C}$ \\
\hline $\begin{array}{c}\mathrm{COCH}_{3-}^{-} \\
15\end{array}$ & & & $1.87,{ }^{\mathrm{c}} \mathrm{s}$ & $\begin{array}{l}23.2,{ }^{\mathrm{e}} \\
\mathrm{CH}_{3}\end{array}$ & $2.11,^{g} \mathrm{~s}$ & $20.8,{ }^{\mathrm{j}} \mathrm{CH}_{3}$ \\
\hline
\end{tabular}

a-j Interchangeable signals.

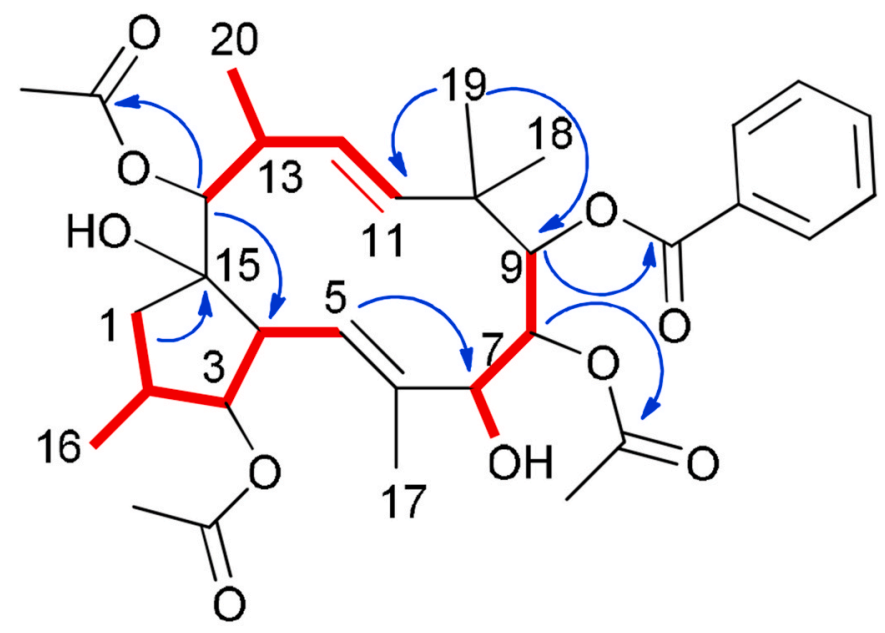

\section{Selected ${ }^{1} \mathrm{H}-{ }^{1} \mathrm{H}$ COSY correlations}

\section{$\frown$ Selected HMBC correlations}

Fig. 2. Selected ${ }^{1} \mathrm{H}-{ }^{1} \mathrm{H}$ COSY and HMBC correlations for 3 .

free hydroxy group as attached to $\mathrm{C}-8$ due to the correlations observed for protons $\mathrm{H}-8\left(\delta_{\mathrm{H}} 3.91 \mathrm{ppm}\right)$ and $\mathrm{OH}-8\left(\delta_{\mathrm{H}} 3.02 \mathrm{ppm}\right)$. Finally, the remaining one acetoxy group could only be located at C-15. The NOESY correlation of $\mathrm{H}-14 / \mathrm{H}-13, \mathrm{H}-4 / \mathrm{H}-13 / \mathrm{H}-11, \mathrm{H}-4 / \mathrm{H}_{3}-17 / \mathrm{H}-7 / \mathrm{H}-8$ and $\mathrm{H}-$ $8 / \mathrm{H}_{3}-18$ confirmed that the 14 -OAc group was $\beta$-oriented. Furthermore, the NOESY cross-peaks of $\mathrm{H}-9 / \mathrm{H}_{3}-19, \mathrm{H}_{3}-19 / \mathrm{H}-12$ and $\mathrm{H}-12 / \mathrm{H}_{3}-20$ revealed $\beta$-orientations. According to the above evidences, the biogenetically consistency for an $\alpha$-orientation of H-4 of a large variety of known jatrophanes (Fakunle et al., 1989), and above described ECD data for related compound 3 , the absolute configuration of compound 4 was defined as $2 R, 3 S, 4 S, 7 S, 8 S, 9 S, 13 S, 14 S, 15 R$ (Fig. 5).

The gCOSY correlation between $\mathrm{H}-7\left(\delta_{\mathrm{H}} 4.10 \mathrm{ppm}\right)$ and $\mathrm{OH}-7\left(\delta_{\mathrm{H}}\right.$ $3.97 \mathrm{ppm}$ ) in compound 5 confirmed the presence of a hydroxyl group at C-7. Thus, the acetoxy groups were attached at C-3, C-8, C-14 and C-15. Furthermore, ${ }^{1} \mathrm{H}$ NMR data revealed evident differences in comparison to compounds 3 and 4 , with a slightly deshielded for $\mathrm{H}-3\left(\delta_{\mathrm{H}} 5.18 \mathrm{ppm}\right.$ in compound 5 vs $\delta_{\mathrm{H}} 4.38 \mathrm{ppm}$ and $\delta_{\mathrm{H}} 4.62 \mathrm{ppm}$ in compounds 3 and 4, respectively). Steric interactions existing between protons and their neighbouring groups would result in a van-der-Waals effect that might lead to the deshielding of the protons (Günther, 2013). Furthermore, it was observed a similar chemical shift for the signals $\mathrm{H}-1 \alpha$ and $\mathrm{H}-1 \beta$ in compound $5\left(\delta_{\mathrm{H}} 2.46 \mathrm{ppm}\right.$ for $\mathrm{H}-1 \alpha$ and $\delta_{\mathrm{H}} 2.31 \mathrm{ppm}$ for $\left.\mathrm{H}-1 \beta\right)$ whereas protons $\mathrm{H}-1 \beta$ are deshielded and protons $\mathrm{H}-1 \alpha$ shielded in compounds 3 and $4\left(\delta_{\mathrm{H}} 1.21 \mathrm{ppm}\right.$ for $\mathrm{H}-1 \alpha$ and $\delta_{\mathrm{H}} 1.67 \mathrm{ppm}$ for $\mathrm{H}-1 \beta$ in compound 3; 


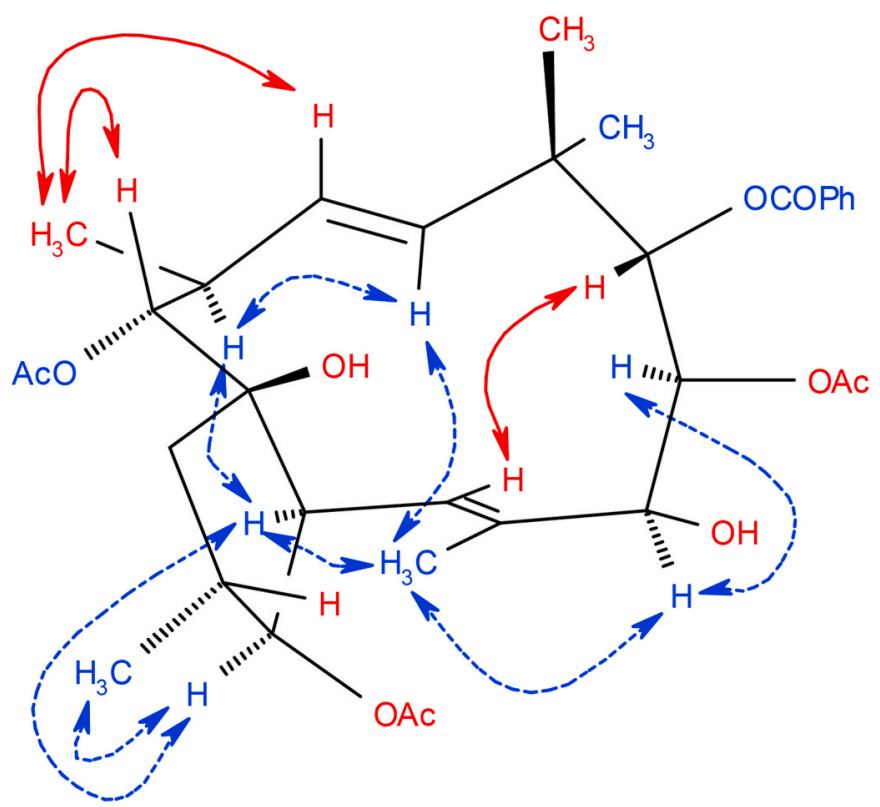

Fig. 3. Selected NOESY correlations exhibited by 3. $\beta$-face correlations in red and $\alpha$-face correlations in blue. (For interpretation of the references to colour in this figure legend, the reader is referred to the Web version of this article.)

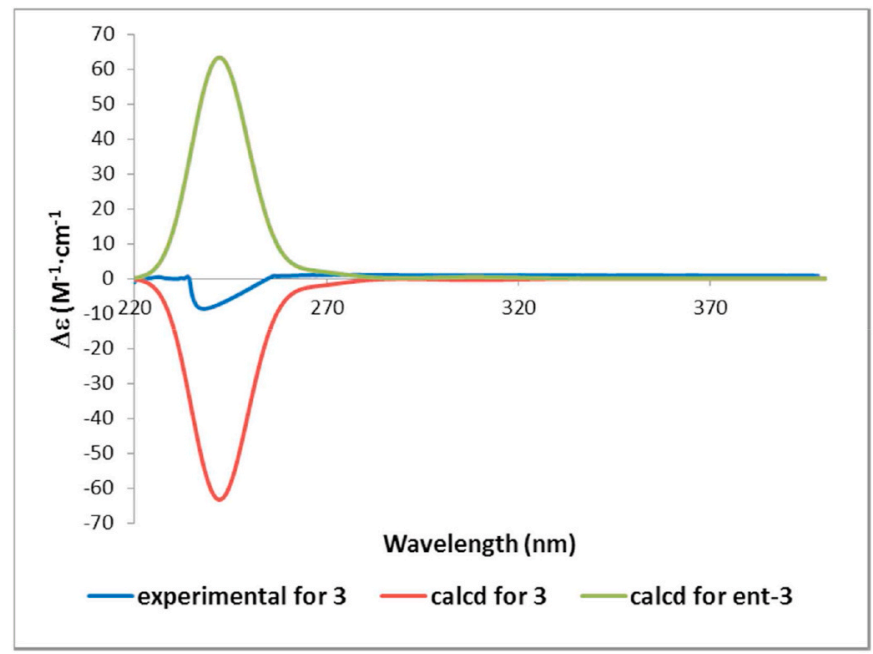

Fig. 4. Experimental and calculated ECD for $\mathbf{3}$.

$\delta_{\mathrm{H}} 1.34 \mathrm{ppm}$ for $\mathrm{H}-1 \alpha$ and $\delta_{\mathrm{H}} 3.54 \mathrm{ppm}$ for $\mathrm{H}-1 \beta$ in compound 4$)$. These features pointed out a different configuration at C-2 position in compound 5, which was also supported by the smaller $J_{4,3}(4.6 \mathrm{~Hz})$ in comparison to compounds 3 and $4\left(J_{4,3}=9.2 \mathrm{~Hz}\right)$. The NOESY cross-peaks of $\mathrm{H}-2 / \mathrm{H}-3, \mathrm{H}-3 / \mathrm{H}-4, \mathrm{H}-4 / \mathrm{H}-13$ and $\mathrm{H}-13 / \mathrm{H}-14$ suggested the $\alpha$-orientation of H-2, H-3, H-13 and H-14. Furthermore, the NOESY cross-peaks of $\mathrm{H}-7 / \mathrm{H}-8$ indicated that these protons were also co-facial with $\alpha$-orientations whereas the NOESY cross-peaks of $\mathrm{H}-9 / \mathrm{H}_{3}-19$ and $\mathrm{H}_{3}-19 / \mathrm{H}_{3}-20$ revealed $\beta$-orientations. Thus, based on the above described evidence and on similar grounds than those presented for compound $\mathbf{4}$, the structure of $\mathbf{5}$ was therefore determined as $(2 S, 3 S, 4 S$, $7 S, 8 S, 9 S, 13 S, 14 S, 15 R)-3,8,14,15$-tetraacetoxy-9-benzoyloxyja-

tropha-5E,11E-dien-7-ol (Fig. 6).

The spectroscopic data of $\mathbf{6}$ are in agreement with those reported in the literature (Flores-Giubi et al., 2017).

Finally, compounds 1-6 were tested on reactivation of latent HIV-1. In a range of concentrations between 1 and $25 \mu \mathrm{g} / \mathrm{mL}$, none of the tested

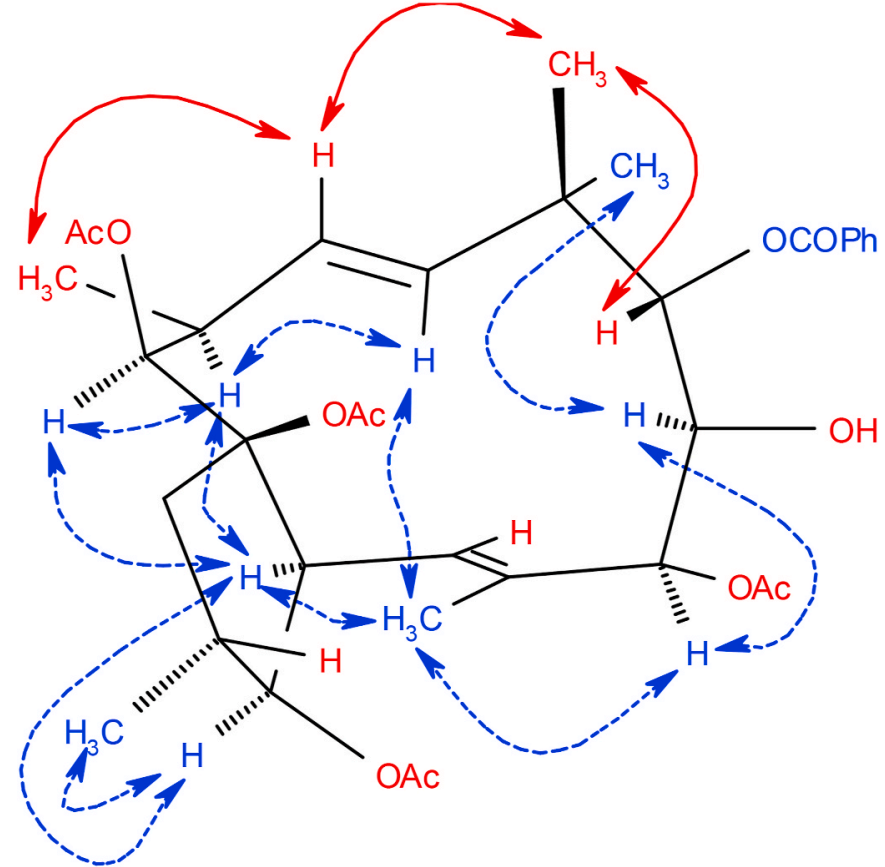

Fig. 5. Selected NOESY correlations exhibited by 4. $\beta$-face correlations in red and $\alpha$-face correlations in blue. (For interpretation of the references to colour in this figure legend, the reader is referred to the Web version of this article.)

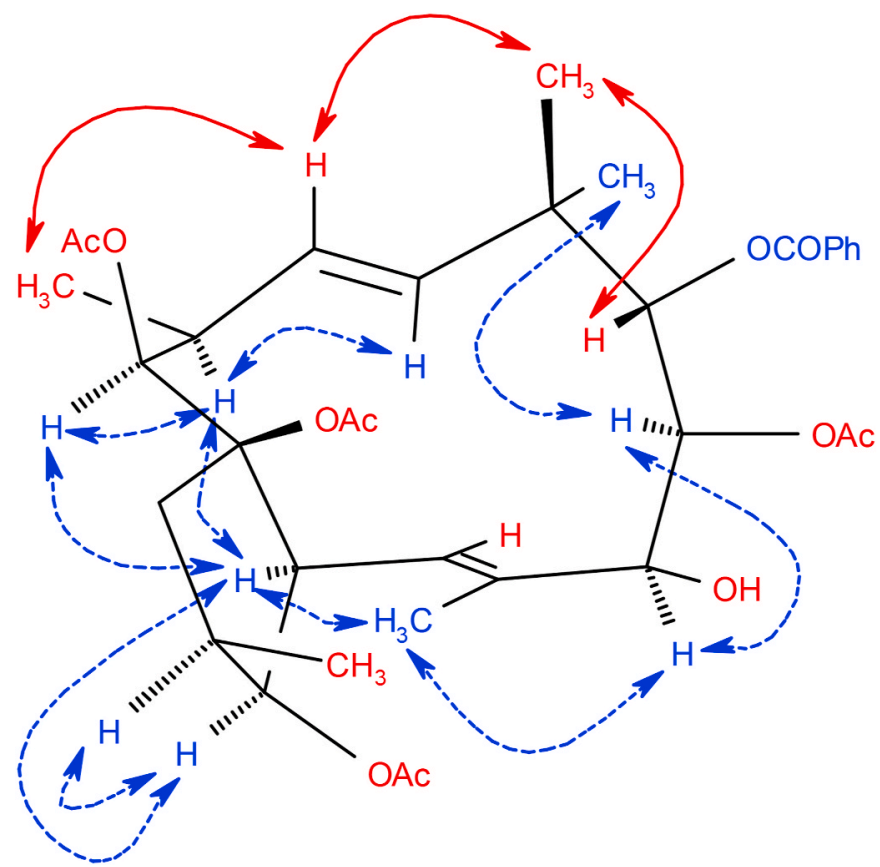

Fig. 6. Selected NOESY correlations exhibited by 5. $\beta$-face correlations in red and $\alpha$-face correlations in blue. (For interpretation of the references to colour in this figure legend, the reader is referred to the Web version of this article.)

compounds showed significant activity as compared to controls. These results agreed with previous studies that have shown that acetylation of the 15-hydroxyl and acetoxylation at C-2 are critical for the HIV-1 latency antagonizing activity (Bedoya et al., 2009).

\subsection{Biosynthetic study of the intramolecular $[2+2]$ cycloaddition}

The isolation of 6 , the proposed biosynthetic precursor for 
gaditanone (2), from E. gaditana Coss encouraged us to gain insight on the nature of the intramolecular $[2+2]$ cycloaddition leading to the gaditanane skeleton by computational analysis. Two possible biosynthetic routes were hypothesized (Fig. 7). On the one hand, the jatrophane ester 1 might undergo cyclization following the pathway A to obtain a tetra-fused derivative (7) that could be further oxidized to form gaditanone (2). On the other hand, a previous oxidation of 1 leading to 6 would be a required step, previous to its cyclization to yield gaditanone (2) (pathway B).

In a cycloaddition reaction there is an electron density transfer from the nucleophilic to the electrophilic species (Kumar et al., 2016; Qiu et al., 2018). In order to translate this concept into a computational analysis, a recent methodology has been used for obtaining bond reactivity indices $\left(\Delta f_{i}^{N B O}\right.$ ) (Sánchez-Márquez, 2016; 2018; Morales-Bayuelo et al., 2018) and philicities for every Natural Bond Orbital (NBO). These bond reactivity indices are obtained through projection of the function dual descriptor on the localized orbitals obtained in the NBO analysis allowing the reaction site of an electrophile or nucleophile to be determined within a much-localized molecular region. A negative small value of $\Delta f_{i}^{N B O}$ together with a high partial occupancy indicates a nucleophilic behaviour whereas a positive value of $\Delta f_{i}^{N B O}$ and a small partial occupancy corresponds to an electrophilic behaviour. For instance, this approach has been successfully applied to study previously the regioselectivity in Diels-Alder reactions (Morales-Bayuelo et al., 2018). In addition, in this study, a Second-Order Perturbational Theory Analysis (SOPTA) (Reed et al., 1988) has been also used to complement and corroborate the results. To the best of our knowledge, these quantum methodologies have not been previously applied in clarifying biosynthetic pathways of terpenes.

Firstly, the pathway A proposed in Fig. 7 was studied considering a singlet state in a concerted mechanism. Therefore, in compound 1 the $\pi$ bonding orbitals 167 (C11-C12), ${ }^{\S} 168$ (C5-C6) and the $\pi$ anti-bonding orbitals 181 (C11-C12) and 182 (C5-C6) would be responsible for the formation of the four-membered ring (Table S3, Supporting information; Jatrophane numbering has been used for describing the orbital interactions throughout the manuscript. For correspondence between jatrophane and gaussian numbering used in table S3, see Table S2 of Supporting Information). However, a [2+2] cycloaddition it does not seem to be very favoured in that model, since the virtual orbitals 181 and 182 have little electrophilic character $\left(\Delta f_{i}^{N B O} 0.054\right.$ and 0.058 , respectively). Furthermore, they have very high orbital energy and according to the geometry that the model predicts, they are a long way from the occupied orbitals to interact with them (Table S3, Supporting information). As in the previous case, in an alternative non-concerted mechanism through triplet state, the formation of the carbocycle would occur by the interaction of the $\pi$ bonding orbitals 170 (C5-C6), ${ }^{\S}$ 171 (C11-C12) and the $\pi$ anti-bonding orbitals 181 (C5-C6) and 182 (C11-C12) (Table S4, Supporting information; For correspondence between jatrophane and gaussian numbering used in table S4, see Table S2 of Supporting Information). The NBO 170 transfers its electronic charge to the NBO 181 whereas the NBO 171 transfers to NBO 182. In contrast to the triplet state concerted mechanism, the $\pi$ bonding NBOS 170 (C5-C6) and 171 (C11-C12) showed lesser nucleophilic character $\left(\Delta f_{i}^{N B O}-0.126\right.$ and -0.222 , respectively) and the $\pi$ anti-bonding NBOs 181 (C5-C6) and 182 (C11-C12) showed a decrease in the electrophilic character $\left(\Delta f_{i}^{N B O} 0.028\right.$ and 0.054 , respectively). Moreover, the unpaired electrons according to the model appeared in the benzoyl moiety (Fig. S5, Supporting Information). Consequently, neither the singlet state concerted, nor the triplet state non-concerted mechanisms seem to be favoured making pathway A an unlikely alternative. In order to verify these results, compound $\mathbf{1}$ was treated with a catalytic amount of benzophenone under UV light (Flores-Giubi et al., 2017) and it did not undergo $[2+2]$ cycloaddition.

On the other hand, it was carried out orbital energy diagrams of the singlet and triplet states of compound 6 (Fig. 7, Pathway B). In the singlet state, NBO $182(\mathrm{C} 5-\mathrm{C} 6)^{\S}$ showed a high electrophilic character (see $\Delta f_{\mathrm{i}}^{N B O}$ in Table S6, Supporting Information). However, NBO 181 (C11-C12) showed a much less electrophilic character, with $\Delta f_{i}^{N B O}$ values below NBOs 172 and 176 respectively located on carbonyl group at C-7 and on carbonyl of benzoate substituent at C-9. Furthermore, NBOs $161(\mathrm{C} 11-\mathrm{C} 12)$ and $162(\mathrm{C} 5-\mathrm{C} 6)^{\S}$ are highly stabilized since they are located below the occupied NBOs 163-171 in the orbital diagram, disfavouring the orbital interactions (Table S6, Supporting Information; For correspondence between jatrophane and gaussian numbering used in table S6, see Table S5 of Supporting Information). If a non-concerted mechanism is considered, two new lone pairs type orbitals appeared in

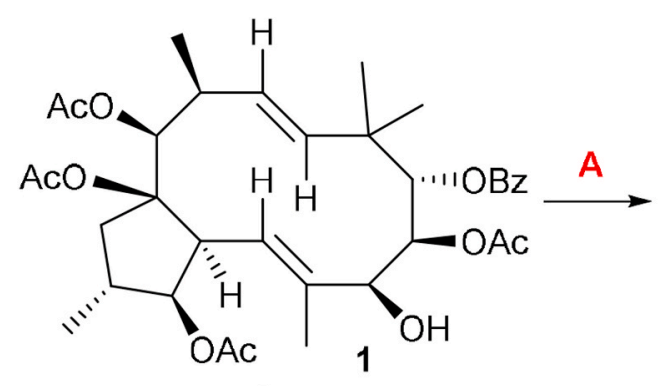<smiles></smiles>

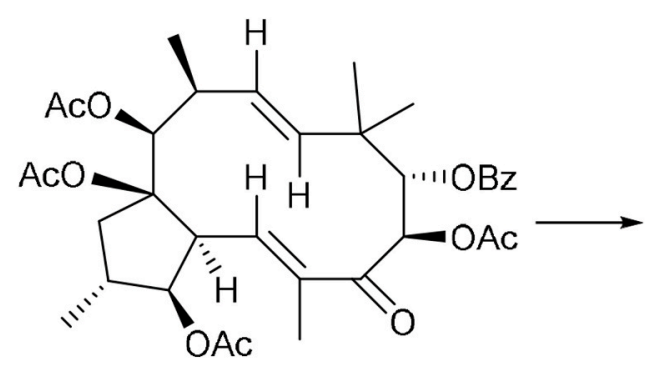

6

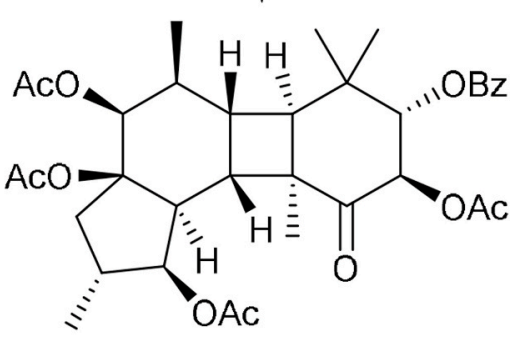

gaditanone (2)

Fig. 7. Proposed biosynthetic routes. 
C-5 (NBO 172) and in the oxygen of the carbonyl group at C-7 (NBO 163), and a new double bond C6-C7 (NBO 160) is formed (Table S7, supporting information). The proposed resonance structures of unpaired electrons in the triple state are shown in Fig. 8. The comparison of the resonance structures with the orbital diagram for this state showed a full correspondence of structure II with the new orbitals (see Fig. S7) described for the triplet-state (Table S7, Supporting Information; For correspondence between jatrophane and gaussian numbering used in table S7, see Table S5 of Supporting Information).

The $\Delta f_{\mathrm{i}}^{N B O}$ values (Table S7, supporting information) indicated that the radical electron NBO $172(\mathrm{C} 5)^{\S}\left(\Delta f_{\mathrm{i}}^{\mathrm{NBO}}-0.386\right)$ has the highest nucleophilic character and the second radical electron is found in orbital $163(\mathrm{C} 7-\mathrm{CO})^{\S}\left(\Delta f_{\mathrm{i}}^{N B O}-0.042\right)$ that has a slight nucleophilic character. On the other hand, the $\pi$ bonding NBO $160(\mathrm{C} 6-\mathrm{C} 7)^{\S}$ showed the highest electrophilic character $\left(\Delta f_{i}^{N B O} 0.295\right)$. This information indicates that C5 is very nucleophilic and C6 very electrophilic (Fig. S7, Supporting Information). For this reason, the interaction with the occupied orbital $162(\mathrm{C} 11-\mathrm{C} 12)$ and the virtual orbital $182(\mathrm{C} 11-\mathrm{C} 12)^{\S}$ would give rise to the $\mathrm{C} 5-\mathrm{C} 11$ and $\mathrm{C} 12-\mathrm{C} 6$ bonds in gaditanone (2). These interactions were corroborated in the SOPTA study, which showed two important interactions. The first one between the NBO $163(\mathrm{C} 7-\mathrm{CO})^{\S}$ and the $\pi$ antibonding NBO 173 (C6-C7) $)^{\S}$ with a value for energy of $8.19 \mathrm{kcal} / \mathrm{mol}$, and a second interaction of NBO $163(\mathrm{C} 7-\mathrm{CO})^{\S}$ with the anti-bonding NBO $194(\text { C7-C8 })^{\S}$ with energy equal to $9.99 \mathrm{kcal} / \mathrm{mol}$. These interactions would stabilize by delocalization the structures shown in Fig. 8.

In contrast to pathway A, the excitation from singlet to triplet seems to be determinant in the change of reactivity of the orbitals involved in the pathway B.

\section{Conclusions}

The bond reactivity indices study suggests that the intramolecular [2 +2 ] cycloaddition leading to gaditanone (2) proceeds through a photochemical non-concerted mechanism of the enone $\mathbf{6}$. The stereoselectivity of the cycloaddition could be understood by the delocalization of electron density over specific NBOs presumably originated from the steric effects of the substituents in the transition state avoiding the cis/trans isomerization (Corey et al., 1964). Furthermore, the formation of a cyclohexanone moiety in the 5/6/4/6-fused tetracyclic ring skeleton both in gaditanone (2) (Flores-Giubi et al., 2017) and heliosterpenoids A and B (Mai et al., 2017) seems to play a structural stabilization role, favouring the cyclization of the jatrophane precursors.

\section{Experimental}

\subsection{General experimental procedures}

Unless otherwise noted, materials and reagents were obtained from commercial suppliers and were used without further purification. Optical rotations were determined with a digital polarimeter. Infrared spectra were recorded on a FT-IR spectrophotometer and reported as wave number $\left(\mathrm{cm}^{-1}\right)$. ECD and UV spectra were recorded on a JASCO J$1500 \mathrm{CD}$ spectrometer. ${ }^{1} \mathrm{H}$ and ${ }^{13} \mathrm{C}$ NMR measurements were recorded on Agilent $500 \mathrm{MHz}$ NMR spectrometer with $\mathrm{SiMe}_{4}$ as the internal reference. Chemical shifts were referenced to $\mathrm{CDCl}_{3}\left(\delta_{\mathrm{H}} 7.25, \delta_{\mathrm{C}} 77.0\right)$.

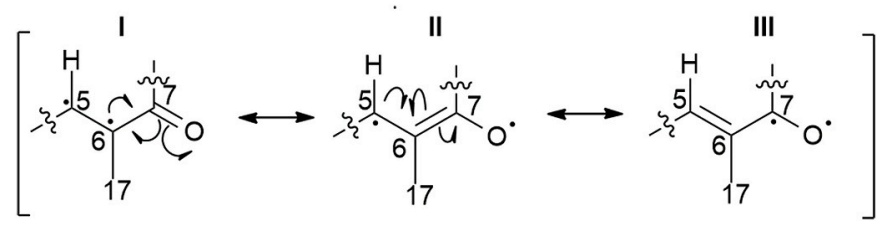

Fig. 8. Possible resonance structures of unpaired electrons in the triplet state of 6 .
NMR assignments were made using a combination of 1D and 2D techniques. High resolution mass spectroscopy (HRMS) was performed in a QTOF mass spectrometer in the positive ion ESI mode. Purification by semi-preparative and analytical HPLC was performed with a Hitachi/ Merck L-6270 apparatus equipped with a differential refractometer detector (RI-7490). A LiChrospher ${ }^{\circledR}$ Si gel $60(5 \mu \mathrm{m})$ LiChroCart ${ }^{\circledR}(250$ $\mathrm{mm} \times 4 \mathrm{~mm})$ column and a LiChrospher ${ }^{\circledR}$ Si gel $60(10 \mu \mathrm{m})$ LiChroCart ${ }^{\circledR}$ $(250 \mathrm{~mm} \times 10 \mathrm{~mm})$ were used in isolation experiments. Silica gel (Merck) was used for column chromatography. TLC was performed on Merck Kiesegel $60 \mathrm{~F}^{25} 4,0.25 \mathrm{~mm}$ thick.

\subsection{Plant material}

Due to Euphorbia gaditana Coss (Euphorbiaceae) being an endangered species, R. H. G. was authorized by Consejería de Medio Ambiente of Junta de Andalucia to collect and manipulate samples of this species in order to carry out the present phytochemical study. The whole plants of E. gaditana Coss were collected at Los Parralejos (Vejer de la Frontera), Cádiz, Spain $\left(36.34^{\circ} \mathrm{N}, 5.97^{\circ} \mathrm{W}\right)$, in June 2011 during the dry season by Dr. L. Plaza-Arregui (Consejería de Medio Ambiente of Junta de Andalucia) and J. Luis Rendón (Botanical Garden of San Fernando, Cádiz). A voucher specimen (accession number: 44-11-0101) was deposited at Herbarium of University of Seville (Spain).

\subsection{Extraction and isolation}

The air-dried plant $(1.8 \mathrm{~kg}$ ) was powdered and extracted with $2.5 \mathrm{~L}$ of $\mathrm{MeOH}$ at room temperature for $3 \times 24 \mathrm{~h}$. The $\mathrm{MeOH}$ extract from the aerial parts and roots were evaporated under reduced pressure to yield a crude extract of $92 \mathrm{~g}$ and $11 \mathrm{~g}$, respectively. The extract of the aerial was suspended in water $(1 \mathrm{~L})$ and then partitioned with petroleum ether $(2$ $\mathrm{L})$, dichloromethane $(1 \mathrm{~L})$, and ethyl acetate $(1 \mathrm{~L})$ sequentially to give the corresponding petroleum ether $(10.9 \mathrm{~g})$, dichloromethane $(0.5 \mathrm{~g})$ and ethyl acetate $(27.2 \mathrm{~g})$ fractions. The petroleum ether-soluble extract showed diterpene signals according to ${ }^{1} \mathrm{H}$ NMR spectra and a portion (1.36 g) was subjected to column chromatography over silica gel, eluting with an increasingly polar gradient of ethyl acetate $(0-100 \%)$ in petroleum ether, to afford 16 fractions (A1-A16), according to TLC analysis. Fractions (A6-A10) presented similar TLC profiles and were combined and further purified by analytical HPLC, to yield 1 (54 mg), 2 (1.4 mg), 3 (13.6 mg), 4 (8.2 mg), 5 (6.8 mg) and 6 (14.6 mg).

In a similar way, the extract from the roots was fractionated into petroleum ether $(1 \mathrm{~g})$, dichloromethane $(0.1 \mathrm{~g})$, and ethyl acetate $(1.6 \mathrm{~g})$ fractions. The petroleum ether fraction was further fractionated to perform the jatrophanes 1 ( $28 \mathrm{mg}), 2$ (13.3 mg), 3 ( $8.3 \mathrm{mg}$ ) and 4 (36 $\mathrm{mg})$.

\subsection{Structural characterization of compounds 1-6}

\subsection{1. (2R,3S, $4 S, 7 S, 8 S, 9 S, 13 S, 14 S, 15 R)-3,8,14,15$-Tetraacetoxy-9- benzoyloxyjatropha-5E, 11 E-dien-7-ol (1)}

The spectroscopic data of $\mathbf{1}$ were in agreement to those described in literature (Flores-Giubi et al., 2017).

\subsubsection{Gaditanone (2)}

The spectroscopic data of $\mathbf{2}$ were according to those described in literature (Flores-Giubi et al., 2017).

\subsection{3. (2R,3S, 4S, 7S, 8S, 9S, 13S, 14R,15R)-3,8,14-Triacetoxy-9- benzoyloxy-jatropha-5E, 11 E-dien-7,15-diol (3)}

Amorphous solid; $[\alpha]=-130\left(c \quad 0.18, \mathrm{CHCl}_{3}\right)$; HPLC (Hex:EtOAc 80:20), $t_{\mathrm{R}}=47 \mathrm{~min}$, flow $3.0 \mathrm{~mL} / \mathrm{min}$; UV $(\mathrm{MeOH}) \lambda_{\max }(\log \varepsilon) 214$ (4.33), 255 (1.11), 2.89 (0.77) nm; ECD (c, $6.7 \times 10-4 \mathrm{M}, \mathrm{MeOH}) \lambda_{\max }$ $(\Delta \varepsilon) 205$ (1.03), 212 (-8.36), 221 (0.10), 238 (-8.70), $256(0.72) \mathrm{nm}$; ${ }^{1} \mathrm{H}$ NMR data $\left(\mathrm{CDCl}_{3}, 500 \mathrm{MHz}\right)$ (see Table 1$) ;{ }^{1} \mathrm{H}$ NMR data $\left(\mathrm{C}_{6} \mathrm{D}_{6}, 500\right.$ $\mathrm{MHz}$ ) (see Table S8, SI); ${ }^{13} \mathrm{C}$ NMR data $\left(\mathrm{CDCl}_{3}, 125 \mathrm{MHz}\right.$ ) (see Table 1); 
IR (KBr) $\nu_{\max } 3450$ (br), 2968, 1736, 1368, 1276, 1235, 1117, 1026, 757, $714 \mathrm{~cm}^{-1}$; HRESIMS: $\mathrm{m} / z$ 623.2834 $[\mathrm{M}+\mathrm{Na}]^{+}$(calcd for $\mathrm{C}_{33} \mathrm{H}_{44} \mathrm{O}_{10} \mathrm{Na}, 623.2832$ ).

\subsection{4. (2R,3S, $4 S, 7 S, 8 S, 9 S, 13 S, 14 S, 15 R)-3,7,14,15$-Tetraacetoxy-9-}

benzoyloxyjatropha-5E,11 E-dien-8-ol (4)

Amorphous solid; $[\alpha]=-92\left(c \quad 0.15, \mathrm{CHCl}_{3}\right)$; HPLC (Hex:EtOAc 70:30), $t_{\mathrm{R}}=24 \mathrm{~min}$, flow $3.0 \mathrm{~mL} / \mathrm{min}$; IR (KBr) $\nu_{\max } 3486$, (br) 2968 , 2933, 1738, 1369, 1238, 1137, 1097, 1069, 759, $712 \mathrm{~cm}^{-1}$; ${ }^{1} \mathrm{H}$ NMR data $\left(\mathrm{CDCl}_{3}, 500 \mathrm{MHz}\right.$ ) (see Table 1$) ;{ }^{13} \mathrm{C}$ NMR data $\left(\mathrm{CDCl}_{3}, 125 \mathrm{MHz}\right)$ (see Table 1); HRESIMS: $m / z 665.2946 \quad[\mathrm{M}+\mathrm{Na}]^{+}$(calcd. for $\left.\mathrm{C}_{35} \mathrm{H}_{46} \mathrm{O}_{11} \mathrm{Na}, 665.2938\right)$.

\subsection{5. (2S, 3S, 4S, 7S, 8S, 9S, 13S, 14S, 15R)-3,8, 14,15-Tetraacetoxy-9-} benzoyloxyjatropha-5E,11 E-dien-7-ol (5)

Amorphous solid; $[\alpha]=-34$ (c 0.11, $\mathrm{CHCl}_{3}$ ); HPLC (Hex:EtOAc 60:40), $t_{\mathrm{R}}=22.6 \mathrm{~min}$, flow $3.0 \mathrm{~mL} / \mathrm{min}$; IR (KBr) $\nu_{\max } 3449$ (br), 2971, 2933, 1738, 1369, 1238, 1119, 1024, $716 \mathrm{~cm}^{-1} ;{ }^{1} \mathrm{H}$ NMR data $\left(\mathrm{CDCl}_{3}\right.$, $500 \mathrm{MHz}$ ) (see Table 1$) ;{ }^{13} \mathrm{C}$ NMR data $\left(\mathrm{CDCl}_{3}, 125 \mathrm{MHz}\right.$ ) (see Table 1);

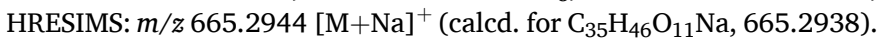

\subsection{6. (2R,3S, $4 S, 8 R, 9 S, 13 S, 14 S, 15 R)-3,8,14,15$-Tetraacetoxy-9- \\ benzoyloxy-jatropha-5E,11 E-dien-7-one (6)}

The spectroscopic data are in agreement with those described in the literature for 6 (Flores-Giubi et al., 2017).

\subsection{Computational methods}

Conformational analysis of $\mathbf{3}$ was performed by using the semiempirical method PM6. The energies, oscillator strengths, and rotational strengths of the first 20 electronic excitations were calculated using a TD-DFT-B3LYP/6-31G++ (d,p) level of theory. The ECD spectrum of the conformer was simulated using a Gaussian function with a half-bandwidth of $0.33 \mathrm{eV}$. The corresponding theoretical ECD spectrum of the enantiomer (ent-3) was depicted by inverting that of 3 . All quantum computations were performed using Gaussian 16 program package (Frisch et al., 2016), on a high performance computer located at CICA (Centro Informático Científico de Andalucía). In the 200-400 nm region, the theoretically calculated ECD spectrum of $\mathbf{3}$ was in good agreement with the experimental ECD spectrum (Fig. 4). This supported the assignment made of the absolute configuration for 3 .

The structures used for the calculation of reactivity descriptor were optimized at B3LYP/6-31G(d) (Becke, 1993; Frisch et al., 1984) level of theory by using the Gaussian16 package (Frisch et al., 2016). UCA-FUKUI software (Sánchez-Márquez et al., 2014) has been used for the calculation of the bond reactivity indices (http://www2.uca.es /dept/quimica_fisica/software/UCA-FUKUI_v2.exe). A detailed description of the methodology implemented in this version of the program has been included in reference (Morales-Bayuelo et al., 2018) in terms of various examples. Molecular orbital images have been obtained with GaussView software (Dennington et al., 2008) and second order perturbational theory analysis has been performed with the code NBO 3.0 (Carpenter and Weinhold, 1988; Glendening et al., 2001; Polo et al., 2019).

\subsection{HIV-1 reactivation assays}

Jurkat-LAT-GFT cells were used in the HIV-1 reactivation assays following the procedure described in the literature (Daoubi et al., 2007).

\section{Declaration of competing interest}

The authors declare that they have no known competing financial interests or personal relationships that could have appeared to influence the work reported in this paper.

\section{Acknowledgments}

This research was supported by a grant from MINECO (RTI 2018099908-BC22). Use of the NMR and MS facilities at the Servicio Centralizado de Ciencia y Tecnología of the University of Cádiz is acknowledged. The authors are grateful to Dr. L. Plaza-Arregui (Consejería de Medio Ambiente of Junta de Andalucía) and J. Luis Rendón (Botanical Garden of San Fernando) for collecting the plant material.

\section{Appendix B. Supplementary data}

Supplementary data to this article can be found online at https://doi. org/10.1016/j.phytochem.2020.112519.

\section{Appendix A. Supplementary data}

1D and 2D NMR spectra, HRESIMS and ECD for compounds 3-5, graphical representation of the values calculated for the NBOs and table with selected ${ }^{13} \mathrm{C}$ NMR data for compounds 3-5 and related jatrophanes.

\section{References}

Andersen, R.J., Ntie-Kang, F., Tietjen, I., 2018. Natural product-derived compounds in HIV suppression, remission, and eradication strategies. Antivir. Res. 158, 63-77. https://doi.org/10.1016/j.antiviral.2018.07.016.

Becke, A.D., 1993. Density-functional thermochemistry. III. The role of exact exchange. J. Chem. Phys. 98, 5648-5652. https://doi.org/10.1063/1.464913.

Bedoya, L.M., Márquez, N., Martínez, N., Gutiérrez-Eisman, S., Álvarez, A., Calzado, M. A., Rojas, J.M., Appendino, G., Muñoz, E., Alcami, J., 2009. SJ23B, a jatrophane diterpene activates classical PKCs and displays strong activity against HIV in vitro. Biochem. Pharmacol. 77, 965-978. https://doi.org/10.1016/j.bcp.2008.11.025.

Blumberg, P.M., Szallasi, Z., 1994. Use of 12-deoxyphorbol 13-monoesters for inhibiting neoplasia and tumor promotion. PCT Int. Appl. WO 9427593.

Bocklandt, S., Blumberg, P.M., Hamer, D.H., 2003. Activation of latent HIV-1 expression by the potent anti-tumor promoter 12-deoxyphorbol 13-phenylacetate. Antivir. Res. 59, 89-98. https://doi.org/10.1016/S0166-3542(03)00034-2.

Brooks, G., Morrice, N.A., Ellis, C., Aitken, A., Evans, A.T., Evans, F.J., 1987. Toxic phorbol esters from Chinese tallow stimulate protein kinase C. Toxicon 25, 1229-1233. https://doi.org/10.1016/0041-0101(87)90141-3.

Carpenter, J.E., Weinhold, F., 1988. Analysis of the geometry of the hydroxymethyl radical by the "different hybrids for different spins" natural bond orbital procedure. J. Mol. Struc-Theochem 169, 41-62. https://doi.org/10.1016/0166-1280(88) 80248-3.

Castro-González, C., Geribaldi-Doldan, N., Murillo-Carretero, M., Domínguez-Riscart, J., Ortiz-Cuellar, P., García-Bernal, F., Flores-Giubi, E., Hernández-Galán, R., MacíasSánchez, A.J., Verastegui-Escolano, C., 2015. Use of 12-deoxyphorbol derivatives to stimulate expansion of neural stem cells. Patent WO 2015086866.

Castro-González, C., Hernández-Galán, R., Macías-Sánchez, A.J., Echeverri, F., GeribaldiDoldan, N., Aguilera-Díaz, A., Domínguez-Riscart, J., Castillo-Rodríguez, A., MurilloCarretero, M., 2013. Culture medium for neural stem cell proliferation. Patent 2404481.

Corea, G., Fattorusso, E., Lanzotti, V., Taglialatela-Scafati, O., Appendino, G., Ballero, M., Simon, P.-N., Dumontet, C., Di Pietro, A., 2003. Jatrophane diterpenes as PGlycoprotein inhibitors. First insights of structure-activity relationships and discovery of a new, powerful lead. J. Med. Chem. 46, 3395-3402. https://doi.org/ 10.1021/jm030787e.

Corey, E.J., Bass, J.D., Le Mahieu, R., Mitra, R.B., 1964. Photochemical reactions of 2cyclohexenones with substituted olefins. J. Am. Chem. Soc. 86, 5570-5583. https:// doi.org/10.1021/ja01078a034.

Daoubi, M., Marquez, N., Mazoir, N., Benharref, A., Hernandez-Galan, R., Munoz, E., Collado, I.G., 2007. Isolation of new phenylacetylingol derivatives that reactivate HIV-1 latency and a novel spirotriterpenoid from Euphorbia officinarum latex. Bioorg. Med. Chem. 15, 4577-4584. https://doi.org/10.1016/j.bmc.2007.04.009.

Dennington, R., Keith, T.A., Millam, J.M., 2008. Gauss View, 5.0.8. Inc., Wallingford CT.

Durán-Peña, M.J., Botubol-Ares, J.M., Collado, I.G., Hernández-Galán, R., 2014. Biologically active diterpenes containing a gem-dimethylcyclopropane subunit: an intriguing source of PKC modulators. Nat. Prod. Rep. 31, 940-952. https://doi.org/ 10.1039/C4NP00008K.

Esposito, M., Nothias, L.-F., Nedev, H., Gallard, J.-F., Leyssen, P., Retailleau, P., Costa, J., Roussi, F., Iorga, B.I., Paolini, J., Litaudon, M., 2016. Euphorbia dendroides latex as a source of jatrophane esters: isolation, structural analysis, conformational study, and anti-CHIKV activity. J. Nat. Prod. 79, 2873-2882. https://doi.org/10.1021/acs. jnatprod.6b00644.

Esposito, M., Nim, S., Nothias, L.-F., Gallard, J.-F., Rawal, M.K., Costa, J., Roussi, F., Prasad, R., Di Pietro, A., Paolini, J., Litaudon, M., 2017. Evaluation of jatrophane esters from Euphorbia spp. as modulators of Candida albicans multidrug transporters. J. Nat. Prod. 80, 479-487. https://doi.org/10.1021/acs.jnatprod.6b00990. 
Fakunle, C.O., Connolly, J.D., Rycroft, D.S., 1989. The structure of enukokurin, a new jatrophane diterpenoid from the latex of Euphorbia lateriflora. J. Nat. Prod. 52, 279-283. https://doi.org/10.1021/np50062a010.

Fattahian, M., Ghanadian, M., Ali, Z., Khan, I.A., 2020. Jatrophane and rearranged jatrophane-type diterpenes: biogenesis, structure, isolation, biological activity and SARs (1984-2019). Phytochemistry Rev. 19, 265-336. https://doi.org/10.1007/ s11101-020-09667-8.

Fei, D.-Q., Dong, L.-L., Qi, F.-M., Fan, G.-X., Li, H.-H., Li, Z.-Y., Zhang, Z.-X., 2016 Euphorikanin A, a diterpenoid lactone with a fused 5/6/7/3 ring system from Euphorbia kansui. Org. Lett. 18, 2844-2847. https://doi.org/10.1021/acs. orglett.6b01093.

Flores-Giubi, E., Geribaldi-Doldán, N., Murillo-Carretero, M., Castro, C., DuránPatrón, R., Macías-Sánchez, A.J., Hernández-Galán, R., 2019. Lathyrane, premyrsinane, and related diterpenes from Euphorbia boetica: effect on in vitro neural progenitor cell proliferation. J. Nat. Prod. 82, 2517-2528. https://doi.org/10.1021/ acs.jnatprod.9b00343.

Flores-Giubi, M.E., Durán-Peña, M.J., Botubol-Ares, J.M., Escobar-Montaño, F., Zorrilla, D., Macías-Sánchez, A.J., Hernández-Galán, R., 2017. Gaditanone, a diterpenoid based on an unprecedented carbon skeleton isolated from Euphorbia gaditana. J. Nat. Prod. 80, 2161-2165. https://doi.org/10.1021/acs. jnatprod.7b00332.

Frisch, M.J., Pople, J.A., Binkley, J.S., 1984. Self-consistent molecular orbital methods. Supplementary functions for Gaussian basis sets. J. Chem. Phys. 80, 3265-3269. https://doi.org/10.1063/1.447079.

Frisch, M.J., Trucks, G.W., Schlegel, H.B., Scuseria, G.E., Robb, M.A., Cheeseman, J.R., Scalmani, G., Barone, V., Petersson, G.A., Nakatsuji, H., Li, X., Caricato, M., Marenich, A.V., Bloino, J., Janesko, B.G., Gomperts, R., Mennucci, B., Hratchian, H. P., Ortiz, J.V., Izmaylov, A.F., Sonnenberg, J.L., Williams-Young, D., Ding, F., Lipparini, F., Egidi, F., Goings, J., Peng, B., Petrone, A., Henderson, T., Ranasinghe, D., Zakrzewski, V.G., Gao, J., Rega, N., Zheng, G., Liang, W., Hada, M. Ehara, M., Toyota, K., Fukuda, R., Hasegawa, J., Ishida, M., Nakajima, T., Honda, Y., Kitao, O., Nakai, H., Vreven, T., Throssell, K., Montgomery Jr., J.A., Peralta, J.E., Ogliaro, F., Bearpark, M.J., Heyd, J.J., Brothers, E.N., Kudin, K.N., Staroverov, V.N., Keith, T.A., Kobayashi, R., Normand, J., Raghavachari, K., Rendell, A.P., Burant, J. C., Iyengar, S.S., Tomasi, J., Cossi, M., Millam, J.M., Klene, M., Adamo, C., Cammi, R., Ochterski, J.W., Martin, R.L., Morokuma, K., Farkas, O., Foresman, J.B., Fox, D.J., 2016. Gaussian, Inc., Wallingford CT.

Geribaldi-Doldan, N., Flores-Giubi, E., Murillo-Carretero, M., García-Bernal, F., Carrasco, M., Macías-Sánchez, A.J., Domínguez-Riscart, J., Verastegui, C., Hernández-Galán, R., Castro, C., 2016. 12-Deoxyphorbols promote adult neurogenesis by inducing neural progenitor cell proliferation via PKC activation. Int. J. Neuropsychopharmacol. 19 (pii), pyv085. https://doi.org/10.1093/ijnp/pyv085. Glendening, E., Badenhoop, J., Reed, A., Carpenter, J., Bohmann, J., Morales, C., Weinhold, F., 2001. NBO 3.0 Program Manual. University of Wisconsin, Madison, WI, USA. http://www.ccl.net/cca/software/MS-WIN95-NT/mopac6/nbo.htm.

Günther, H., 2013. NMR Spectroscopy: Basic Principles, Concepts and Applications in Chemistry, third ed. Wiley-VCH, Germany.

Hohmann, J., Forgo, P., Csupor, D., Schlosser, G., 2003. Isolation and structure determination of new jatrophane diterpenoids from Euphorbia platyphyllos L. Helv. Chim. Acta 86, 3386-3393. https://doi.org/10.1002/hlca.200390282.

Hohmann, J., Molnar, J., Redei, D., Evanics, F., Forgo, P., Kalman, A., Argay, G., Szabo, P., 2002. Discovery and biological evaluation of a new family of poten modulators of multidrug resistance: Reversal of multidrug resistance of mouse lymphoma cells by new natural jatrophane diterpenoids isolated from Euphorbia species. J. Med. Chem. 45, 2425-2431. https://doi.org/10.1021/jm0111301.

Hu, R., Gao, J., Rozimamat, R., Aisa, H.A., 2018. Jatrophane diterpenoids from Euphorbia sororia as potent modulators against P-glycoprotein-based multidrug resistance. Eur. J. Med. Chem. 146, 157-170. https://doi.org/10.1016/j.ejmech.2018.01.027.

Jassbi, A.R., 2006. Chemistry and biological activity of secondary metabolites in Euphorbia from Iran. Phytochemistry 67, 1977-1984. https://doi.org/10.1016/j. phytochem.2006.06.030.

Kinghorn, A.D., 1979. Characterization of an irritant 4-deoxyphorbol diester from Euphorbia tirucalli. J. Nat. Prod. 42, 112-115. https://doi.org/10.1021/ np50001a006.

Kinzel, V., Richards, J., Goerttler, K., Loehrke, H., Fürstenberger, G., Marks, F., 1984. Interaction of phorbol derivatives with replicating cells. IARC Sci. Publ. 56, 253-264.

Krstic, G., Jadranin, M., Todorovic, N.M., Pesic, M., Stankovic, T., Aljancic, I.S., Tesevic, V.V., 2018. Jatrophane diterpenoids with multidrug-resistance modulating activity from the latex of Euphorbia nicaeensis. Phytochemistry 148, 104-112. https://doi.org/10.1016/j.phytochem.2018.01.016.

Kulkosky, J., Culnan, D.M., Roman, J., Dornadula, G., Schnell, M., Boyd, M.R., Pomerantz, R.J., 2001. Prostratin: activation of latent HIV-1 expression suggests a potential inductive adjuvant therapy for HAART. Blood 98, 3006-3015. https://doi org/10.1182/blood.V98.10.3006.

Kumar, S., Kumar, V., Singh, S.P., 2016. Cycloaddition reactions. Pericyclic reactions, pp. 145-229. https://doi.org/10.1016/B978-0-12-803640-2.00004-X.

Li, X.-C., Ferreira, D., Ding, Y., 2010. Determination of absolute configuration of natural products: theoretical calculation of electronic circular dichroism as a tool. Curr. Org. Chem. 14, 1678-1697. https://doi.org/10.2174/138527210792927717.

Ling, T., Lang, W.H., Craig, J., Potts, M.B., Budhraja, A., Opferman, J., Bollinger, J., Maier, J., Marsico, T.D., Rivas, F., 2019. Studies of Jatrogossone A as a reactive oxygen species inducer in cancer cellular models. J. Nat. Prod. 82, 1301-1311. https://doi.org/10.1021/acs.jnatprod.8b01087.

Mai, Z.-P., Ni, G., Liu, Y.-F., Li, L., Li, J.-Y., Yu, D.-Q., 2018a. Heliojatrones A and B, Two jatrophane-derived diterpenoids with a 5/10 fused-ring skeleton from Euphorbia helioscopia: structural elucidation and biomimetic conversion. Org. Lett. 20, 3124-3127. https://doi.org/10.1021/acs.orglett.8b01215.

Mai, Z., Ni, G., Liu, Y., Zhang, Z., Li, L., Chen, N., Yu, D., 2018b. Helioscopianoids A-Q, bioactive jatrophane diterpenoid esters from Euphorbia helioscopia. Acta Pharm. Sin. B 8, 805-817. https://doi.org/10.1016/j.apsb.2018.03.011.

Mai, Z.-P., Ni, G., Liu, Y.-F., Li, L., Shi, G.-R., Wang, X., Li, J.-Y., Yu, D.-Q., 2017. Heliosterpenoids A and B, two novel jatrophane-derived diterpenoids with a 5/6/4/ 6 ring system from Euphorbia helioscopia. Sci. Rep. 7, 4922-4928. https://doi.org/ 10.1038/s41598-017-04399-w.

Márquez, N., Calzado, M.A., Sánchez-Duffhues, G., Pérez, M., Minassi, A., Pagani, A., Appendino, G., Díaz, L., Muñoz-Fernández, M.A., Muñoz, E., 2008. Differential effects of phorbol-13-monoesters on human immunodeficiency virus reactivation. Biochem. Pharmacol. 75, 1370-1380. https://doi.org/10.1016/j.bcp.2007.12.004.

Meng, X.-H., Wang, K., Chai, T., Guo, Z.-Y., Zhao, M., Yang, J.-L., 2020. Ingenane and jatrophane diterpenoids from Euphorbia kansui and their antiproliferative effects. Phytochemistry 172, 112257. https://doi.org/10.1016/j.phytochem.2020.112257.

Miglietta, A., Gabriel, L., Appendino, G., Bocca, C., 2003. Biological properties of jatrophane polyesters, new microtubule-interacting agents. Canc. Chemother. Pharmacol. 51, 67-74. https://doi.org/10.1007/s00280-002-0541-4.

Morales-Bayuelo, A., Sánchez-Márquez, J., Jana, G., Chattaraj, P.K., 2018. Analyzing torquoselectivity in a series of unusual ring-opening reactions through bond reactivity indices and the adaptive natural density partitioning method. Int. J. Quant. Chem. 118 https://doi.org/10.1002/qua.25778 n/a.

Olivier, G.W.J., Rowan, M.G., Branch, S.K., Mahon, M.F., Molloy, K.C., 1992. Two esters of synadenol, a new lathyrane diterpenoid, from the latex of Synadenium compactum (Euphorbiaceae): a crystal structure analysis. J. Chem. Soc., Perkin Trans. 1, 1831-1835. https://doi.org/10.1039/P19920001831.

Polo, E., Arce-Parada, V., López-Cortés, X.A., Sánchez-Márquez, J., Morales-Bayuelo, A., Forero-Doria, O., Gutiérrez, M., 2019. Synthesis of pyrazolo-fused 4-azafluorenones in an ionic liquid. Mechanistic insights by joint studies using DFT analysis and mass spectrometry. Catalysts 9, 820. https://doi.org/10.3390/catal9100820.

Qiu, M., Jin, J., Zhou, L., Zhou, W., Liu, Y., Tan, Q., Cao, D., Zhao, Z., 2018. Diterpenoids from Croton crassifolius include a novel skeleton possibly generated via an intramolecular [2+2]-photocycloaddition reaction. Phytochemistry 145, 103-110. https://doi.org/10.1016/j.phytochem.2017.10.008.

Reed, A.E., Curtiss, L.A., Weinhold, F., 1988. Intermolecular interactions from a natural bond orbital, donor-acceptor viewpoint. Chem. Rev. 88, 899-926. https://doi.org/ 10.1021/cr00088a005.

Remy, S., Litaudon, M., 2019. Macrocyclic diterpenoids from euphorbiaceae as a source of potent and selective inhibitors of chikungunya virus replication. Molecules 24, 2336-2351. https://doi.org/10.3390/molecules24122336.

Roux, P.P., Ballif, B.A., Anjum, R., Gygi, S.P., Blenis, J., 2004. Tumor-promoting phorbol esters and activated Ras inactivate the tuberous sclerosis tumor suppressor complex via p90 ribosomal S6 kinase. Proc. Natl. Acad. Sci. U. S. A. 101, 13489-13494. https://doi.org/10.1073/pnas.0405659101.

Sabandar, C.W., Ahmat, N., Jaafar, F.M., Sahidin, I., 2013. Medicinal property, phytochemistry and pharmacology of several Jatropha species (Euphorbiaceae): a review. Phytochemistry 85, 7-29. https://doi.org/10.1016/j phytochem.2012.10.009.

Sánchez-Máquez, J., Zorrilla, D., García, V., Fernández, M., 2018. Introducing a new bond reactivity index: philicities for natural bond orbitals. J. Mol. Model. 24, 1-16. https://doi.org/10.1007/s00894-017-3553-z.

Sánchez-Márquez, J., 2016. Introducing new reactivity descriptors: "Bond reactivity indices." Comparison of the new definitions and atomic reactivity indices. J. Chem. Phys. 145, 194105. https://doi.org/10.1063/1.4967293 [1-12].

Sánchez-Márquez, J., Zorrilla, D., Sánchez-Coronilla, A., de los Santos, D.M., Navas, J., Fernández-Lorenzo, C., Alcántara, R., Martín-Calleja, J., 2014. Introducing "UCAFUKUI" software: reactivity-index calculations. J. Mol. Model. 20, 2492. https://doi. org/10.1007/s00894-014-2492-1.

Shi, Q.-W., Su, X.-H., Kiyota, H., 2008. Chemical and pharmacological research of the plants in genus Euphorbia. Chem. Rev. 108, 4295-4327. https://doi.org/10.1021/ cr078350s.

Stockwell, B.R., 2004. Exploring biology with small organic molecules. Nature 432, 846-854. https://doi.org/10.1038/nature03196.

Tian, Y., Guo, Q., Xu, W., Zhu, C., Yang, Y., Shi, J., 2014. A minor diterpenoid with a new 6/5/7/3 fused-ring skeleton from Euphorbia micractina. Org. Lett. 16, 3950-3953. https://doi.org/10.1021/ol501760h.

Tian, Y., Xu, W., Zhu, C., Lin, S., Guo, Y., Shi, J., 2013. Diterpenoids with diverse skeletons from the roots of Euphorbia micractina. J. Nat. Prod. 76, 1039-1046. https://doi.org/10.1021/np400029d.

Valente, C., Pedro, M., Ascenso, J.R., Abreu, P.M., Nascimento, M.S.J., Ferreira, M.-J.U., 2004. Euphopubescenol and euphopubescene, two new jatrophane polyesters, and lathyrane-type diterpenes from Euphorbia pubescens. Planta Med. 70, 244-249. https://doi.org/10.1055/s-2004-815542.

Vasas, A., Hohmann, J., 2014. Euphorbia diterpenes: isolation, structure, biological activity, and synthesis (2008-2012). Chem. Rev. 114, 8579-8612. https://doi.org/ $10.1021 /$ cr400541j.

Vasas, A., Redei, D., Csupor, D., Molnar, J., Hohmann, J., 2012. Diterpenes from european Euphorbia species serving as prototypes for natural-product-based drug discovery. Eur. J. Org Chem. 5115-5130 https://doi.org/10.1002/ejoc.201200733.

Wan, L.-S., Nian, Y., Peng, X.-R., Shao, L.-D., Li, X.-N., Yang, J., Zhou, M., Qiu, M.-H., 2018. Pepluanols C-D, two diterpenoids with two skeletons from Euphorbia peplus. Org. Lett. 20, 3074-3078. https://doi.org/10.1021/acs.orglett.8b01114.

Wan, L.-S., Nian, Y., Ye, C.-J., Shao, L.-D., Peng, X.-R., Geng, C.-A., Zuo, Z.-L., Li, X.-N., Yang, J., Zhou, M., Qiu, M.-H., 2016. Three minor diterpenoids with three carbon 
skeletons from Euphorbia peplus. Org. Lett. 18, 2166-2169. https://doi.org/10.1021/ acs.orglett.6b00787.

Wang, H.-B., Wang, X.-Y., Liu, L.-P., Qin, G.-W., Kang, T.-G., 2015. Tigliane diterpenoids from the euphorbiaceae and Thymelaeaceae families. Chem. Rev. 115, 2975-3011. https://doi.org/10.1021/cr200397n.

Weinstein, I.B., Lee, L.-S., Fisher, P.B., Mufson, A., Yamasaki, H., 1979. Action of phorbol esters in cell culture: mimicry of transformation, altered differentiation, and effects on cell membranes. J. Supramol. Struct. 12, 195-208. https://doi.org/10.1002/ jss.400120206.
Zhang, J., He, J., Cheng, Y.-C., Zhang, P.-C., Yan, Y., Zhang, H.-J., Zhang, W.K., Xu, J.-K., 2019. Fischernolides A-D, four novel diterpene-based meroterpenoid scaffolds with antitumor activities from Euphorbia fischeriana. Org. Chem. Front. 6, 2312-2318. https://doi.org/10.1039/C8Q001379A.

Zhao, N.-D., Ding, X., Song, Y., Yang, D.-Q., Yu, H.-L., Adelakun, T.A., Qian, W.-D., Zhang, Y., Di, Y.-T., Gao, F., Hao, X.-J., Li, S.-L., 2018. Identification of ingol and rhamnofolane diterpenoids from Euphorbia resinifera and their abilities to induce lysosomal biosynthesis. J. Nat. Prod. 81, 1209-1218. https://doi.org/10.1021/acs. jnatprod.7b00981. 